\title{
MODAL ANALYSIS OF REAL TIMBER FRAME HOUSES WITH DIFFERENT INSULATION MATERIALS
}

\author{
Marcin Szczepański ${ }^{1}$, Wojciech Migda ${ }^{1}$, Robert Jankowski ${ }^{1}$ \\ ' Department of Civil and Environmental Engineering, Gdansk University of Technology, Narutowicza 11/12, \\ 80-233 Gdańsk, Poland, e-mail: marszcze@pg.gda.pl,wmigda@pg.gda.pl, jankowr@pg.gda.pl
}

Received: 2016.05.11

Accepted: 2016.07.04

Published: 2016.09.01

\begin{abstract}
The aim of this article is to present the results of a numerical modal analysis of two actual structures of timber frame buildings and the different behaviour due to the used insulation material. One model of the timber structure was filled with mineral wool, while the other with polyurethane foam. During the modal analysis, eigenvalues for both models have been determined. The results of the analysis clearly show the increase of stiffness and damping properties of skeletal constructions achieved by the use of polyurethane foam as the skeleton filling. The numerical model was based on prior experimental test on real scale single frame elements, therefore the result can be assumed to be adequate.
\end{abstract}

Keywords: timber-frame house, earthquake resistance, dynamic, numerical model, modal analysis.

\section{INTRODUCTION}

Construction technology has a huge impact on aspects related to the preparation of the investment process where the selection of appropriate building materials plays a very important role. Looking at the construction technology for small houses resistant to the influence of dynamic loads, including seismic and paraseismic excitations (see. $[13,17,18]$ ), one of the most attractive materials for this type of construction is wood. This development is certainly enhanced by the recent emphasis put on the environmental and energy-saving features of such structures used in the construction of passive houses [6].

Accordingly, in relation to the technology, designed timber structures also exhibit relatively good resistance to dynamic actions, including extreme earthquakes [10]). As a sheathing of walls, ceilings and roofs of timber frame houses, waterresistant wood-based panels for example MFP or OSB $/ 3$ are used primarily. Those boards have very good mechanical properties, stiffen the entire structure, and thanks to resistance to shear forces, reduce the acting force transmitted to the structure under dynamic loads [10].

Frame timber houses are sometimes able to survive a catastrophic earthquake with only minor damage as proven with experiences in North America and Japan [10]. Therefore, the use of a suitable material as wall sheathing has a beneficial effect on the horizontal shearing and dissipates energy leading to stiffening of the structure $[7,8]$. Timber frame houses are relatively rigid in terms of structure stiffness, and lightweight and therefore showing good resistance to dynamic actions carried by ground, like earthquakes, as well as paraseismic and impact loads $[3,9,19,20]$.

Mechanisms of structural damage of skeletal timber houses have been repeatedly observed during earthquakes. The degree of destruction generated in a timber building during an earthquake depends on the seismic intensity [5].

An important element of the proper use of frameworks is also the thermal insulation. Depending on the used material for thermal insulation, the insulation can have significant 
influence on the behaviour of the building during earthquakes or it can have almost no effect $[14,15]$.

The study on mechanical properties of various insulating materials also shows their usefulness as a structure-insulating and structure-stiffening material. The most common material to isolate the structure is mineral wool but this material does not improve the mechanical properties of the timber structure $[13,14,15,16]$.

Another kind of insulation material is polyurethane (PU) foam. Due to the closed cell structure and mechanical properties, polyurethane foam increases the rigidity of the timber frame structure $[14,15,16]$.

The purpose of this article is to present the results of the comparison of modal analysis of two numerical models of actual structure of timber frame buildings, insulated with mineral wool and with polyurethane foam. Both models have identical geometric parameters of the material and differ only in the used thermal insulation. In order to perform a modal analysis, material parameters have been verified by experimental studies $[14,15]$.

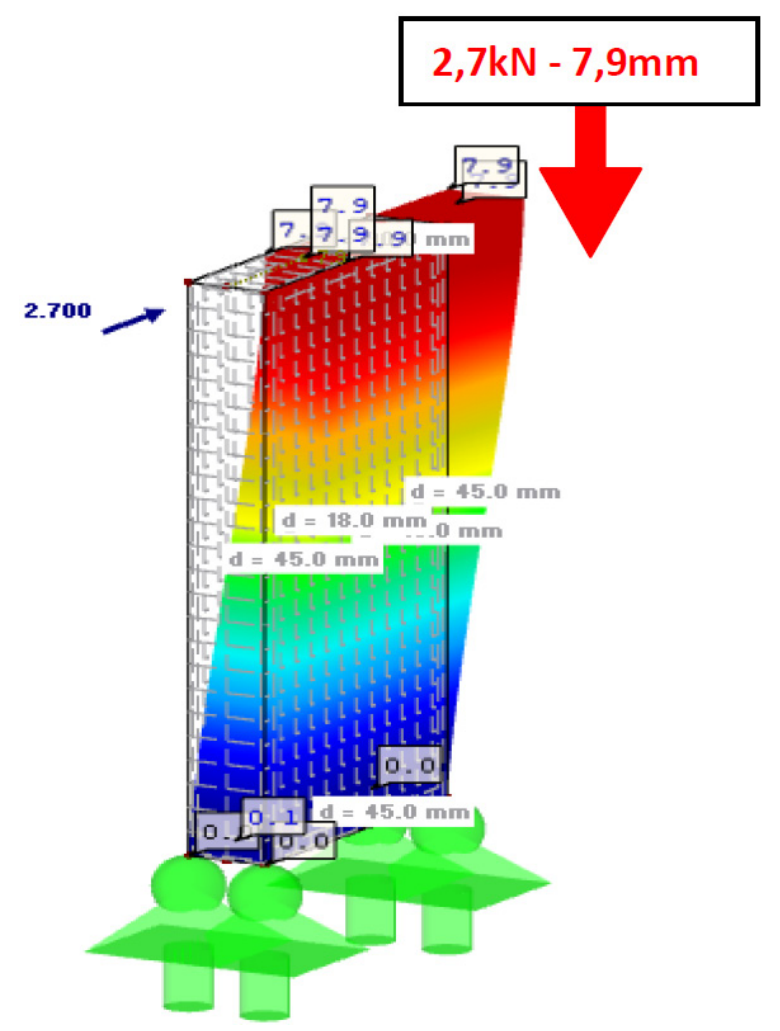

Fig. 1.Validation of numerical models of external walls with load $2,7 \mathrm{kN}$

\section{EXPERIMENTAL STUDIES AND NUMERICAL MODELS OF EXTERNAL WALLS}

Experimental studies have been conducted to verify the behaviour of the two models of exterior walls, using two different insulation materials. Both walls were made in the traditional technology of construction of wooden houses one of which is filled with mineral wool and the other with polyurethane foam.

A single frame, constructed of solid wood and OSB3 sheathing with different insulation material was subjected to dynamic and static loads in order to obtain hysteresis loops. For this test a specially designed test setup was used. On this basis damping values and rigidity for each model in the test have been calculated.

Examples of the test results for the element filled with mineral wool are:

a) $\mathrm{f}=2 \mathrm{~Hz}$; suppression: $17.09 \%$, stiffness: $416.66 \mathrm{kN} / \mathrm{m}$

b) $\mathrm{f}=5 \mathrm{~Hz}$; suppression: $41.53 \%$, stiffness: $232.55 \mathrm{kN} / \mathrm{m}$,

and the test results for the element filled with polyurethane foam are:

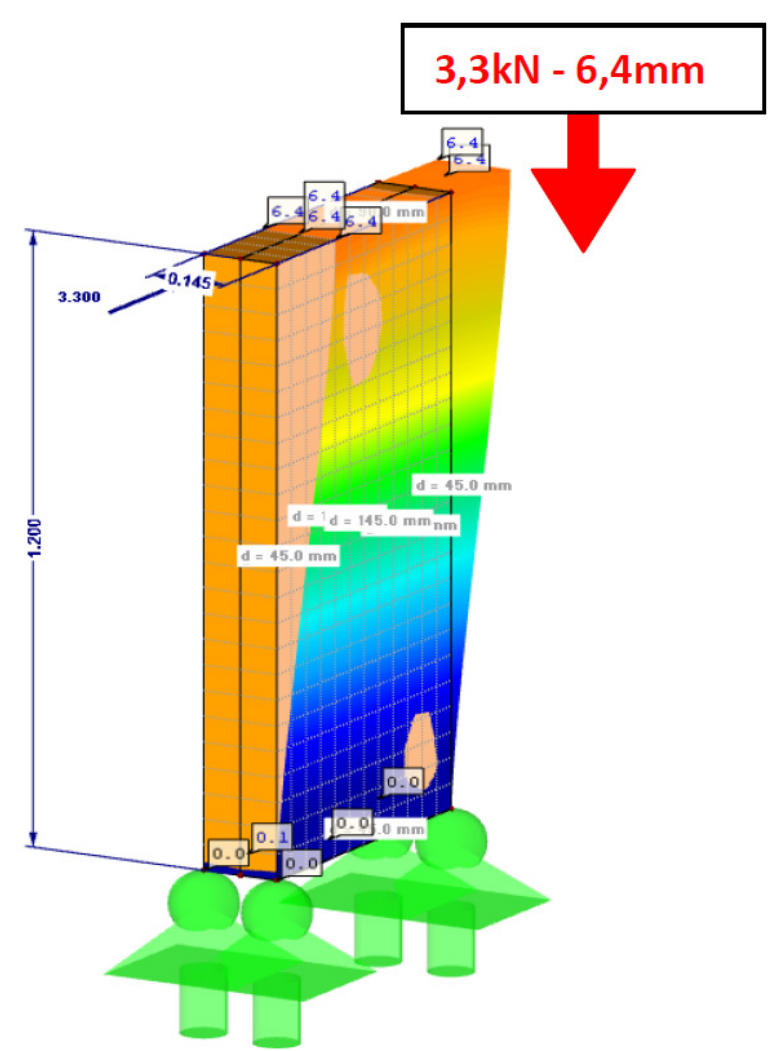

Fig. 2.Validation of numerical models of external walls with load $3,3 \mathrm{kN}$ 
a) $\mathrm{f}=2 \mathrm{~Hz}$; suppression: $22.25 \%$, stiffness: $668.60 \mathrm{kN} / \mathrm{m}$

b) $\mathrm{f}=5 \mathrm{~Hz}$; suppression: $66.40 \%$, stiffness: $387.50 \mathrm{kN} / \mathrm{m}$.

Based on the results a numerical model of a single wall element was proposed. The model was then validated using the displacement as the corresponding value. Both models have been verified positively - figure 1 and 2 [16].

\section{NUMERICAL MODELS OF REAL TIMBER STRUCTURES - MODAL ANALYSIS}

The numerical analysis has been conducted for a one-storey timber building frame structure (as shown in figure 3 and 4) with the following parameters:

- storey height: $2.80 \mathrm{~m}$,

- length and width of the building: $12.0 \mathrm{~m}$.
The building was separated into residential and utility rooms. The design included window and door openings as can be found in a typical project. The timber frame building was modelled with softwood class $\mathrm{C} 30$ enclosed on both sides with OSB3 boards and filled with rock wool in the first model and with polyurethane foam in the second one. In order to model the load of the roof structure and snow load - without the need of modelling all elements in the 3D model, in order to reduce calculation time - the dead weight of the top layer of OSB3 board was increased to 3.0 $\mathrm{kN} / \mathrm{m}^{2}$. The total weight of the designed model was $43087 \mathrm{~kg}$.

The active mass for a given model was dead weight. For numerical calculations of the eigenvalues of the two models used Lanczos method by which obtained 10 as vibrations. Structural damping was adopted on the basis of hysteretic loop obtained from experimental tests of real scale models of external walls elements [14].

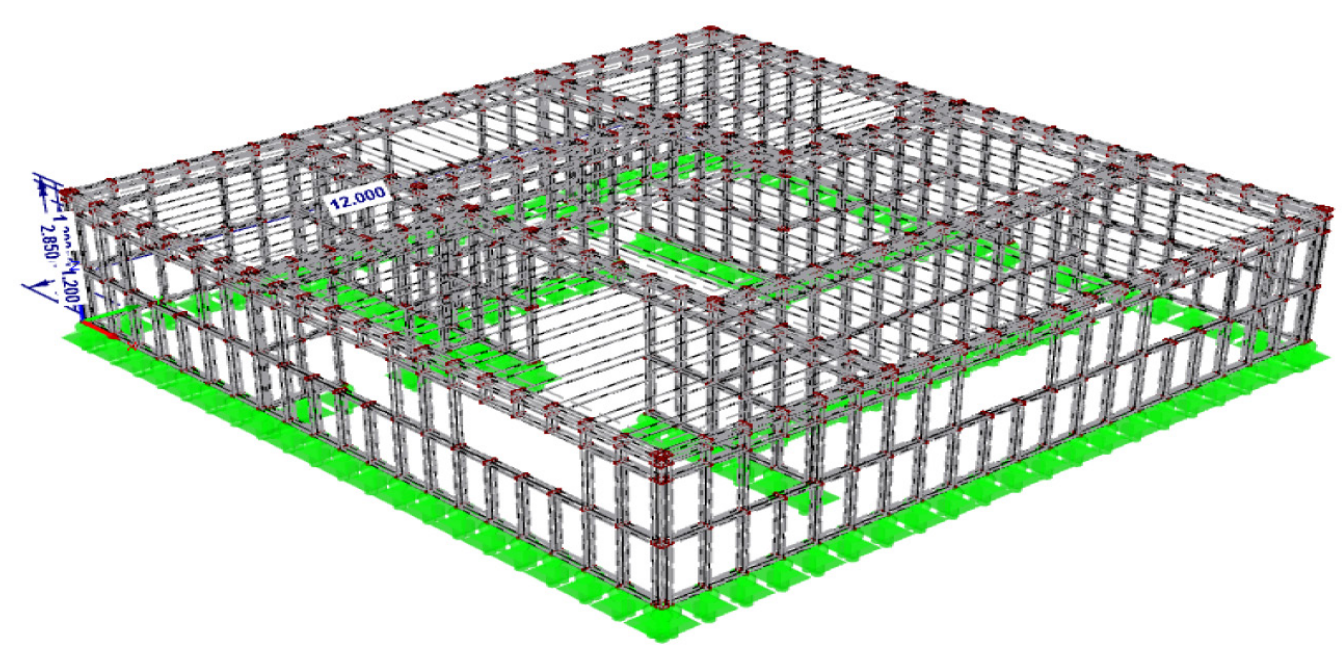

Fig. 3. Model with visible beam elements

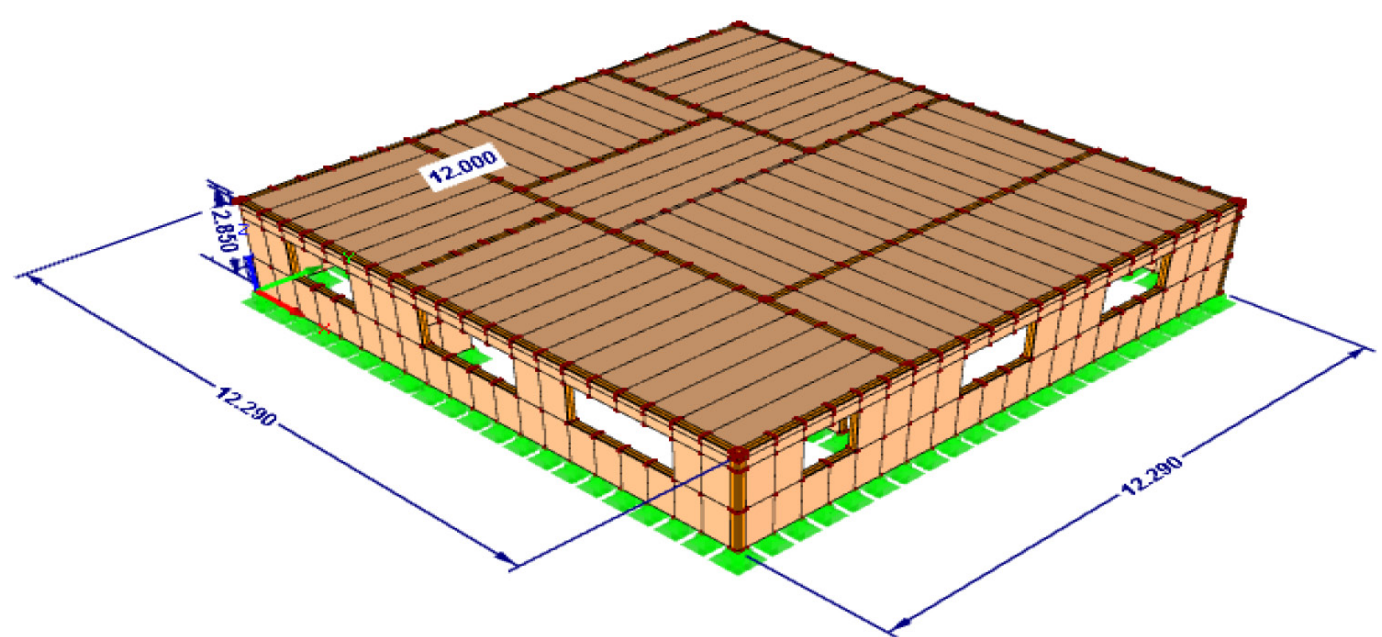

Fig. 4. The final model showing the surface elements 


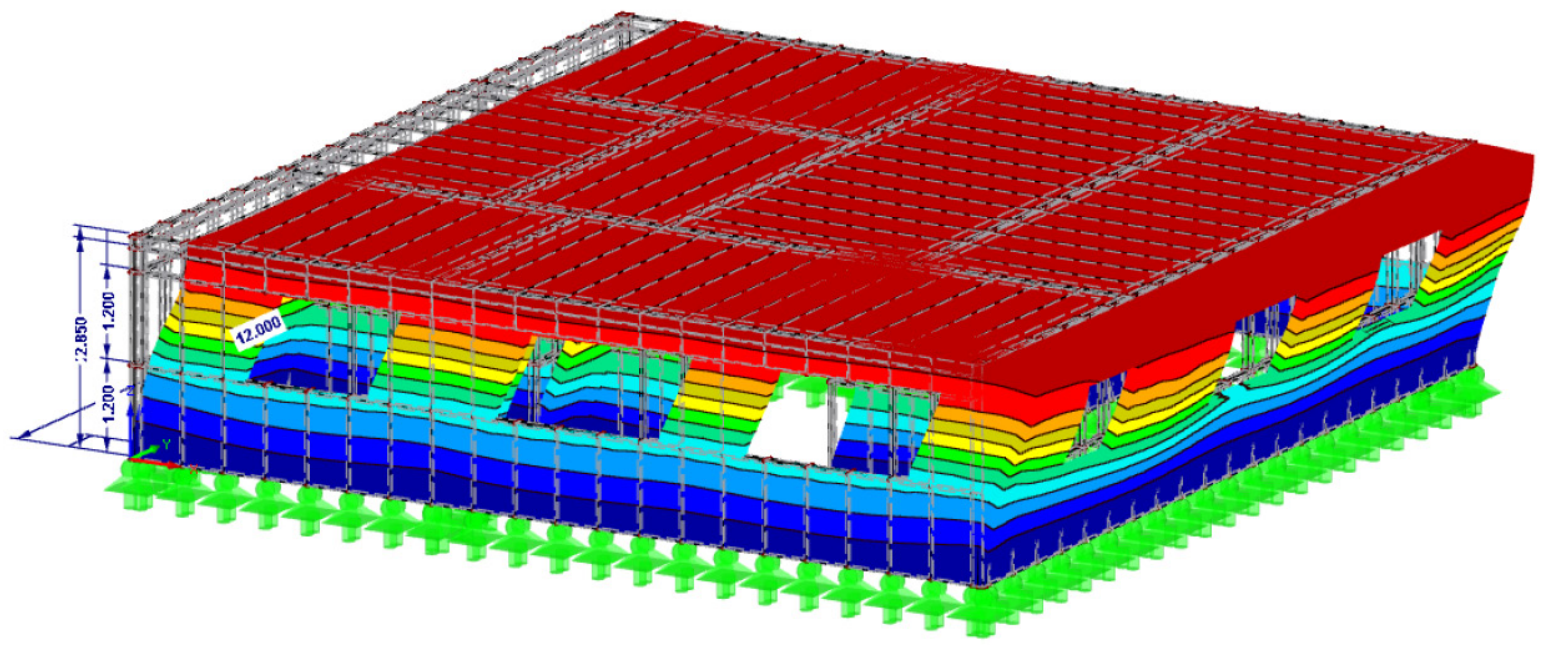

Fig. 5. First natural frequency $\left(f_{1}=1.58 \mathrm{~Hz}\right)$

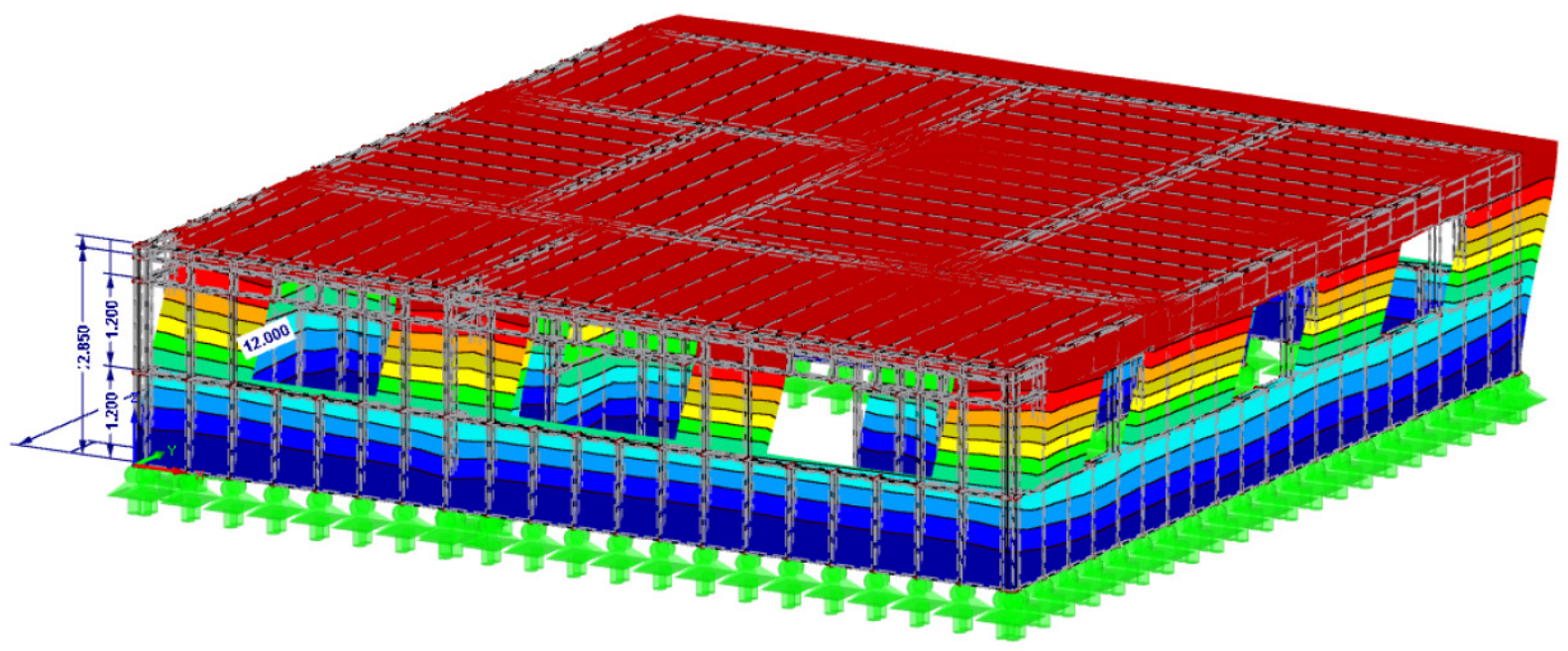

Fig. 6. Second natural frequency $\left(\mathrm{f}_{2}=1.65 \mathrm{~Hz}\right)$

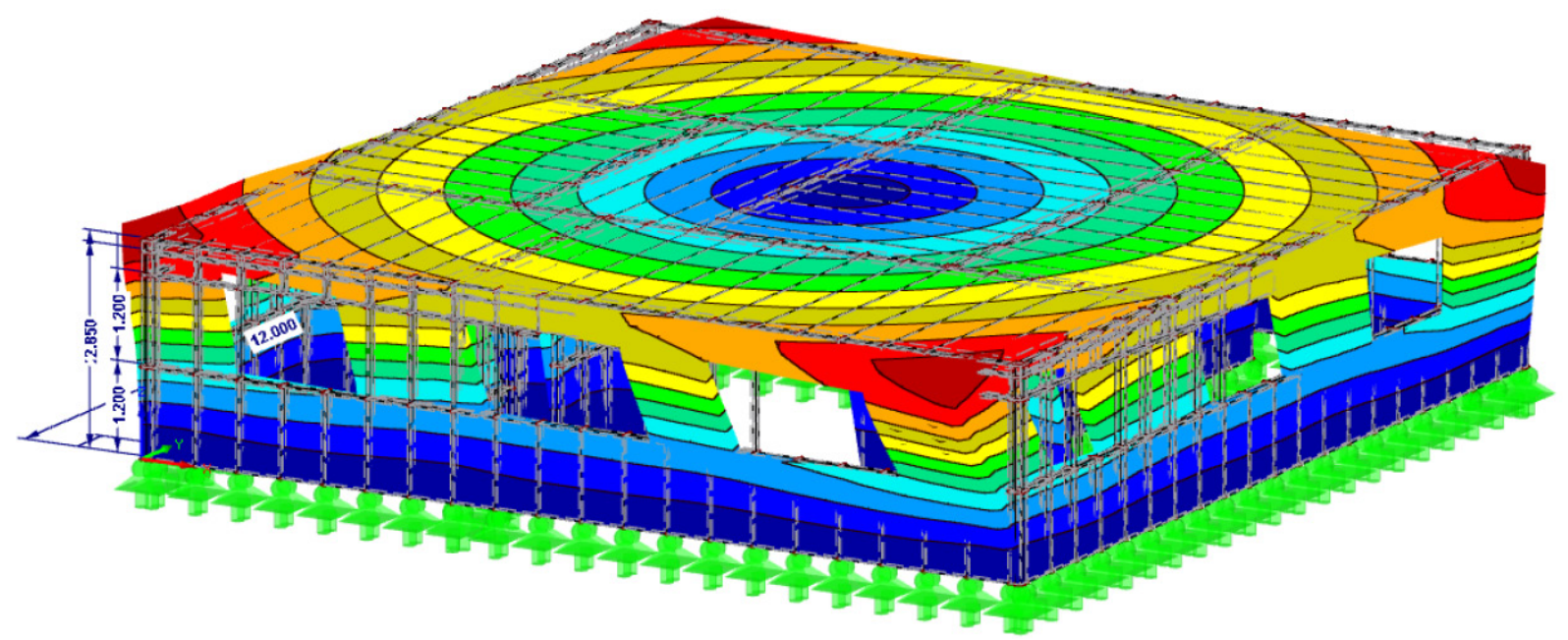

Fig. 7. Third natural frequency $\left(f_{3}=2.11 \mathrm{~Hz}\right)$ 


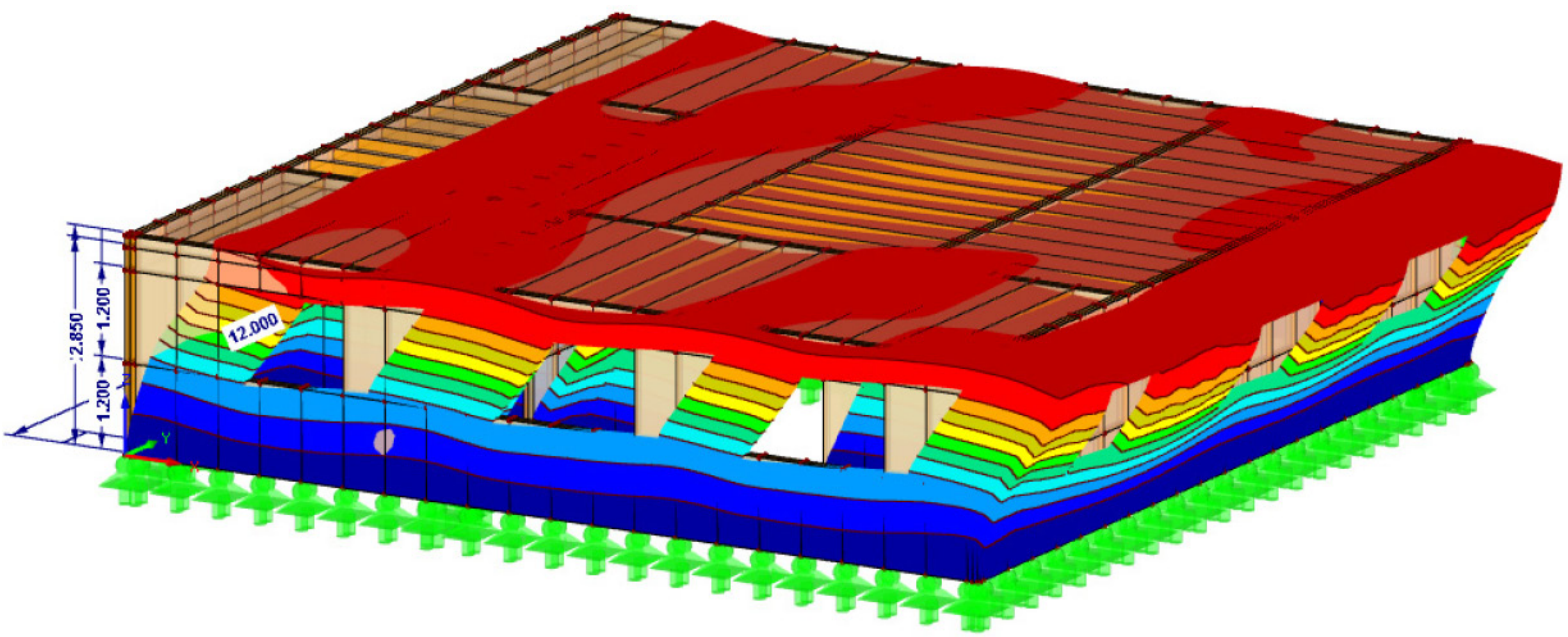

Fig. 8. First natural frequency $\left(\mathrm{f}_{3}=2.72 \mathrm{~Hz}\right)$

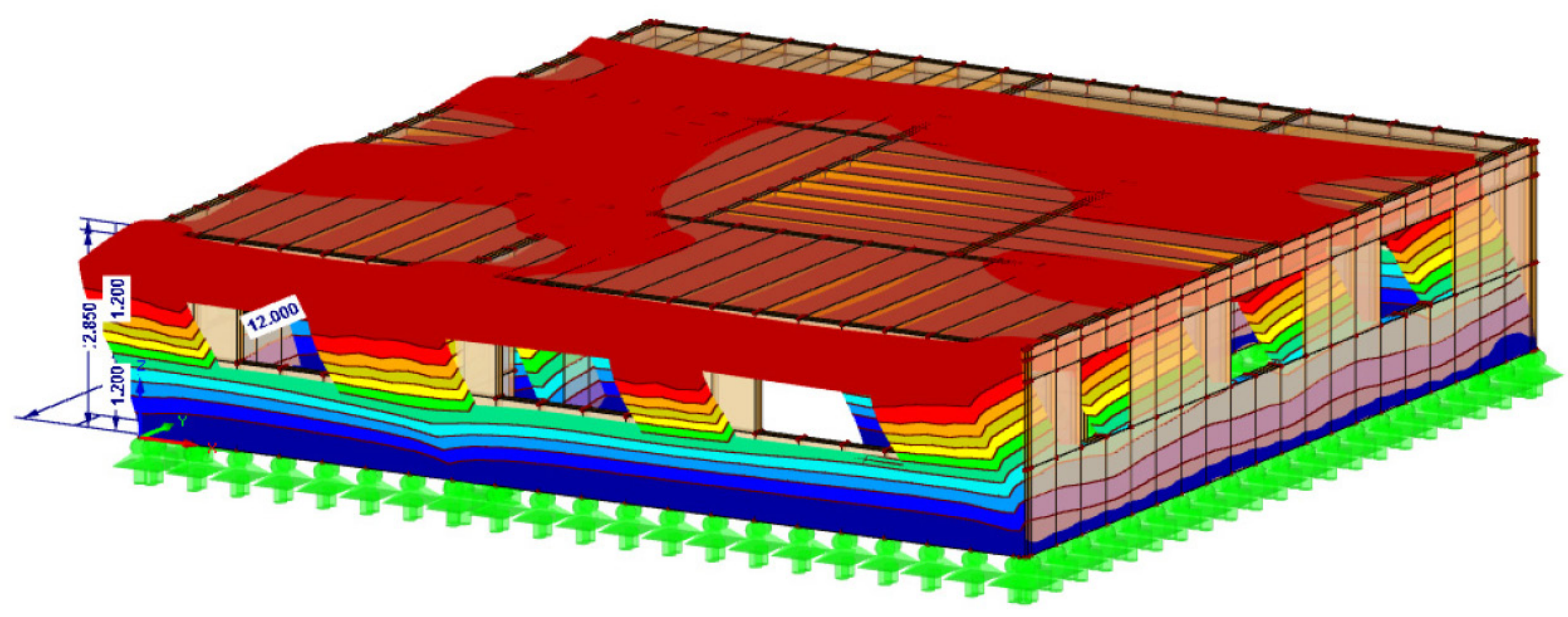

Fig. 9. Second natural frequency $\left(f_{3}=2.92 \mathrm{~Hz}\right)$

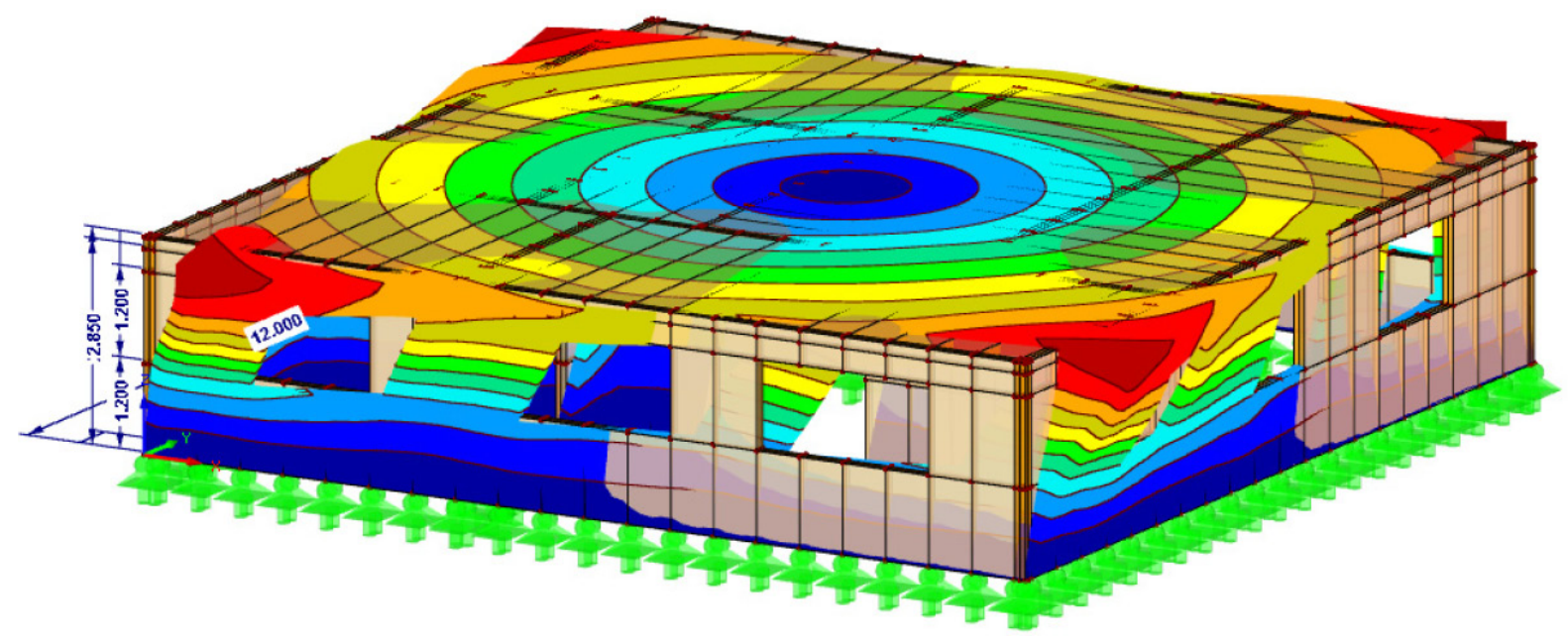

Fig. 10. Third natural frequency $\left(f_{3}=3.78 \mathrm{~Hz}\right)$ 
The numerical model was created by joining many single wall frame elements, for which the numerical results were verified by experimental tests [14], in order to build the presented building model. The values of attenuation parameters obtained in experimental studies, have been confirmed by other researchers as presented in articles $[11,12]$.

For the modal analysis, damping coefficients of Rayleigh in the form of coefficients $\mathrm{a}_{0}$ and $\mathrm{a}_{1}$ have been calculated from the attenuation values obtained from experimental tests. To determine the value of attenuation coefficients, the following formulas were used $[2,4]$ :

$$
\begin{gathered}
\mathrm{a}_{0}=\zeta * 2 * \omega_{1}^{*} \omega_{2} /\left(\omega_{1}+\omega_{2}\right) \\
a_{1}=\zeta * 2 /\left(\omega_{1}+\omega_{2}\right)
\end{gathered}
$$

where: $\mathrm{a}_{0}$ - Rayleigh's damping factor,

$a_{1}$ - Rayleigh's damping factor,

$\zeta$-damping coefficient obtained by experimental investigations [\%], $\omega_{1}, \omega_{2}-$ angular frequency $[\mathrm{rad} / \mathrm{s}]$.

The modal analysis was carried out using Lanczos method. The results for the timber frame building with walls filled with mineral wool and with PU foam are shown in the Table 1.

For the first three eigenvalues of both models a graphical comparative analysis is shown

Table 1. Values of natural frequencies (eigenvalues) left for mineral wool, right for PU foam

\begin{tabular}{|c|c|}
\hline $\begin{array}{c}\text { Filled with mineral wool } \\
\text { model - Natural } \\
\text { Frequency }[\mathrm{Hz}]\end{array}$ & $\begin{array}{c}\text { Filled with PU foam - } \\
\text { Natural Frequency }[\mathrm{Hz}]\end{array}$ \\
\hline 1.58 & 2.68 \\
\hline 1.65 & 2.88 \\
\hline 2.11 & 3.73 \\
\hline 5.17 & 4.97 \\
\hline 5.34 & 5.93 \\
\hline 5.38 & 6.56 \\
\hline 5.45 & 6.73 \\
\hline 5.48 & 7.17 \\
\hline 5.53 & 7.38 \\
\hline 5.62 & 7.73 \\
\hline
\end{tabular}

Table 2. Percentage difference for different wall filling for the first three natural frequencies

\begin{tabular}{|c|c|c|c|}
\hline $\begin{array}{c}\text { Frequency } \\
{[\mathrm{Hz}]}\end{array}$ & Wool filling & $\begin{array}{c}\text { Polyurethane } \\
\text { foam filling }\end{array}$ & $\begin{array}{c}\text { Difference } \\
{[\%]}\end{array}$ \\
\hline $\mathrm{f}_{1}$ & 1.58 & 2.72 & $72.15 \%$ \\
\hline $\mathrm{f}_{2}$ & 1.65 & 2.92 & $76.96 \%$ \\
\hline $\mathrm{f}_{3}$ & 2.11 & 3.78 & $79.14 \%$ \\
\hline
\end{tabular}

below, Figure 5 to 7 are showing the results for the model with mineral wool filled walls, while Figures 8 to 10 are showing the results for the PU foam filled walls.

\section{CONCLUSIONS}

Based on the numerical results of the provided modal analysis of both models it is clearly visible that using polyurethane foam as a filling between the skeletal timber structures has a positive impact in terms of dynamical behaviour. Higher natural frequencies of the model filled with polyurethane foam testify to its greater stiffness - the increase of the natural frequencies (as shown in Table 2) is around $70 \%$, comparing the mineral wool filling with the PU foam filling.

Based on the results of the presented analysis it can be conclude that by substituting mineral wool as thermal insulation by PU foam will increase the stiffness of skeletal timber structures, which improves the resistance of timber frame structures against dynamic loads, such as earthquakes [11]. In order to prove this behaviour the presented models will be subjected in a dynamic analysis to earthquake excitations.

\section{REFERENCES}

1. ECS. Eurocode 8: Design Provisions for Earthquake Resistance of Structures. Brussels. Belgium: European Committee for Standardization. 1998.

2. Chopra K. Dynamic Of Structures. Theory of Applications to Earthquke Engineering. University of California at Berkeley 1995.

3. Jankowski R.. Badania dynamiczne modeli konstrukcji budowlanych na stole wstrząsowym. Czasopismo Techniczne. 2-B/2007, 2007, 29-37.

4. Jankowski R.. Nonlinear rate dependent model of high damping rubber bearing. Bulletin of Earthquake Engineering EAEE. 1 (3), 2003, 397-403.

5. Johan Vessby. Analysis of shear walls for multistorey timber buildings. Linnaeus University Dissertations No 45/2011.

6. Kiyono J.. Furukawa A. Casuality Occurence Mechanism in the Collapse of Timber-Frame House During an Earthquake. Earthquake Engineering and Structural Dynamics, 33, 2004, 1233-1248.

7. Nitka W. Mój Dom z Drewna. Centrum Informacyjne Lasów Państwowych. Warszawa 2010.

8. Pei S. Van de Lindt J.W.. Coupled Shear-Bending Formulation for Seismic Analysis of Stacked Wood 
Shear Wall Systems. Earthquake Engineering and Structural Dynamics, 38, 2009, 1631-1647.

9. Radziszewska-Zielina E. Analiza porównawcza parametrów materiałów termoizolacyjnych mających zastosowanie jako izolacja ścian zewnętrznych. 4/2009. Politechnika Krakowska.

10. Seo J.M.. Choi I.K.. Lee J.R.. Experimental Study on the Aseismic Capacity of a Wooden House Using Shaking Table. Earthquake Engineering and Structural Dynamics, 28, 1999, 1143-1162.

11. Sutoyo D. 2009. Hysteretic characteristics of woodframe structures under seismic otions. Dissertation (Ph.D.), California Institute of Technology. http:// resolver.caltech.edu/CaltechETD:etd-05172009 -153304 .

12. Szczepański M., Jankowski R. Experimental dynamic study on a timber-frame house using shaking table. In: Current Scientific Challenges in Concrete and Steel Structures and Concrete Technology. Gdansk University of Technology, Gdańsk 2011, 155-162.

13. Szczepański M., Migda W., Jankowski R., Construction technology of timber-frame houses resistant to dynamic loads - study on models of exterior walls. Advances in Science and Technology Re- search Journal, 9 (28), 2015, 75-80.

14. Szczepański M.. Jankowski R.. Technologia budowy domów drewnianych o konstrukcji szkieletowej odpornych na wpływy dynamiczne-Eksperymentalne badania modeli ścian zewnętrznych// Inżynieria Morska i Geotechnika, 5, 2013, 405-407.

15. Szczepański M., Migda W., Jankowski R., TimberFrame Houses Resistant to Dynamic Loads - Analysis of Wall Panel Filled with Polyurethane Foam, Virbations in Physical Systems, 27, 2016.

16. Toratti T. Seismic Design of Timber Structures. FEMA. 1994.

17.Zembaty Z., Cholewicki A., Jankowski R., Szulc J., Trzęsienia ziemi 21 września 2004 r. w Polsce północno-wschodniej oraz ich wpływ na obiekty budowlane. Inżynieria i Budownictwo, $\mathrm{Nr} 1$, 2005. 3-9.

18. Zembaty Z., Jankowski R., Cholewicki A., Szulc J., Trzęsienie ziemi 30 listopada 2004 r. na Podhalu oraz jego wpływ na obiekty budowlane. Inżynieria i Budownictwo. Nr 9/2005. s.507-511. 2005.

19. Zarnic R., Dujic B., Study of Rateral Resistance of Massive X-Lam Wooden Wall System Subjected to Horizontal Loads; Earthquake Engineering on Timber Structures. Portugal 2006. 